\title{
Reflecting on the Future: \\ Children and Their Mothers
}

\author{
Marc Briod
}

Oakland University

It seems true, as Heidegger (1962) observed, that the future is ontologically prior to the past and present. We live toward the future. It is an open horizon of life's possibilities, the field of our concerns. We care about what will happen, we anticipate events and experiences, fearing some possibilities, hoping for others, and seeking to realize those that are most nearly within our grasp. In short, we ex-ist. The word existence comes from the Latin existere, to stand ahead of oneself, to stand out in the world, to transcend oneself by standing toward a future that is not yet, that may never be realized.

Others have argued that no temporal dimension has ontological priority (Merleau-Ponty, 1962; Sartre, 1966). If anything, the present may be considered primordial, because time is an upsurge of consciousness into its surrounding world. Through it we gain our presence to things. And this presence is our experience of the present, without which we could have neither past nor future. As Merleau-Ponty (1962) puts it, "there is one single time which is self-confirmatory ... and which establishes itself at a stroke ... in one movement of time-creation" (p. 421). So, he says, it is the essence of the future to be the future of a lived present. This present is not shut up within itself. Even though it may be thought of as a mere instant of time, it can be equally considered this day, this year, or even a whole life. Yet however wide and inclusive the present may seem, it is always the place from which "our past and our future spring forth when we reach out towards them" (p. 421). So, in contrast to Heidegger, Merleau-Ponty concludes that the present enjoys a privilege over future and past.

Still other thinkers, like Freud (1960) and Eliade (1959), have attempted to show the primacy of the past. Freud, for example, describes psychoanalysis as a kind of mental archeology by which the analysand is gradually reconnected to forgotten caverns of a childhood past that will not be denied. He pictures the future as linked to these deep undercurrents-currents that must be understood if one is to live with minimum neuroses.

The four child-mother portraits recounted here reflect futures that are compatible with each of the above emphases. From a Heideggerian point of view, these children stand toward their own futures, sometimes 
resolutely, but often not. As with Merleau-Ponty (1962), they also seem to experience the future through their presence in the world as "a single movement appropriate to itself in all its parts" (p. 419). Finally, as with Freud, their past always already carries a primacy of its own. Its facticity, its legacy, bears down on them as they seek to find meaningful ways to live toward the future.

The future is a common horizon of concern for both child and mother. For purposes of this study, mothers enrolled in undergraduate education courses were simply invited to keep daily journal accounts of conversations with their children. So, when allusions to the future appeared in their journals, they were asssuredly not the result of any specific thematic request from me. Rather, the mothers' remarks about time stood out, for me, from a rich tapestry of spontaneous conversational exchanges with their children. The conversations presented here were selected solely on the basis of their vivid portrayal of the future.

\section{Ryan (9)}

Ryan's mother must work full time in order to put herself through a teacher-training program. She reports that her son experiences time as a restriction that puts him under a great deal of pressure. She writes:

Ryan asked if we could go to the movies this afternoon (a Sunday), but I had to point out that we wouldn't have time to do that and meet obligations we had that evening. "I hate time!" he said. He went on to complain that there was never enough time to do all the things he had to do so that he could do the things he really enjoyed. He also expressed concern that he didn't have enough time to finish in-school assignments by the deadlines, and this caused a great deal of friction between himself and his teacher.

Ryan's distaste for time pressures in his life becomes even more apparent when his mother invites him to describe time. His description is poignant, for it pictures, instead, a timeless world. She reports:

Ryan said that time is determined by the sun. If there were no time there would be four suns shining on all parts of the earth at the same time and everyone would experience warm weather like Florida. No one would get anything done because they wouldn't have a schedule. You might spend too much time doing something because you couldn't tell how much time you spent. Say you went into the woods to track a deer and told your buddy you'd be back in fifteen minutes, but you wouldn't know how long that was, and you might keep going and get lost and never come back. Or you might spend three hours doing something and only have fifteen minutes left to do something that takes a whole hour to do.

Within Ryan's fantasy world of timelessness, time remains an inescapable problem. Whether it's the perpetual Florida sun or the thrill of a future deerhunt, Ryan sees himself haunted by the continuing difficulties of time management. Even in an unguarded moment of fantasy he is imagining the allocation and arranging of time, still dogged by the necessity of keeping track of time, much the way he dreams of tracking a deer. 
Already at age nine he is feeling the invisible tether of time that binds him psychologically to his surrounding social order. It is a continuing and unpleasant revelation to Ryan that he is growing up in a world that will demand more and more of his personal time and attention.

Ryan asked me about the exams I was preparing for tonight, and I showed him a midterm essay test $I$ had taken. He was amazed at the number of pages and amount of writing. He asked how long it took me to finish, and how much time was allowed. I told him it took me the entire two hours to complete my answers. He said he better not go to college because he could never write that fast.

So Ryan is faced with a dilemma. He is realistic enough to see the necessity of adjusting to social time requirements, yet he senses a chasm between what he is and what he is expected to become. Already there are too many routine demands. He looks at his adult future in the light of his present childhood, and he cannot seem to reconcile the two worlds. It is an ominous wind from his own future that blows gently, insistently, toward his fading childhood.

\section{Erik (11)}

Like Ryan, 11-year-old Erik also senses a childhood that is slipping away. As the older of two boys (Tim is nine), he is expected to shoulder many of the responsibilities around the house. His divorced mother works long hours and takes two or three university courses per term in pursuit of an elementary teaching certificate. The resulting time pressure on the family creates a chronic underlying tension. And Erik is frankly bitter about it. His mother writes:

I came home from work and Erik was very angry. He said I never spend any time with him. I asked him what he meant, because I am home almost every night. He said spending time was going to the show, bowling, going to the park and not staying home.

Erik is also under direct personal pressure from his mother to develop habits of self-discipline that will serve him in the future:

I told him he had to practice his piano every day or else, for at least a half an hour. He turns thirty minutes into seven or eight and tries to slip away from the piano. He doesn't feel he needs to put time into anything. He can learn the same, whether it is seven or thirty minutes. He doesn't use time wisely.

So Erik's mother is on a collision course with her son over whether and how he should acquire certain habits and skills deemed important for his future. Erik's response is to become openly hostile about a future that she seems to want for him more badly than he does.

He has trouble getting up in the morning but hates to be late for school. He waits till the last minute to get ready but cries for me to wait for him. In doing so, he makes me late for my school. I try to explain that I get into trouble for being late too. He just shrugs his shoulders and tells me it's too 
bad. I am his mother and I have to take care of him. My time is not as important or valuable as his.

The tragedy here is that the mother wants a future for her son-a future for which her son shows outright disdain. Instead, Erik prefers the old family arrangement when he was still at the center of his mother's attentions. But she will have none of it, since she is under considerable pressure at work and school. Moreover, she wants to shake him loose from his cloying and clinging style of childhood so that he can face his future with discipline and confidence. But her strategy of working and sacrificing to ensure a better life for her boy has not strengthened his desire to become a more autonomous and future-oriented person.

As if to add insult to injury, recently Erik's nine-year-old brother Tim has begun to echo his older brother's message and it cuts her to the bone. She writes:

Tim asked me "Why are you always working? Why don't you spend any time with me?" I told him I would much rather spend time with him than work all the time. He then told me, "I know why you don't spend time with me. It's because you don't love me anymore." I told him it had nothing to do with him. I said I was working so he could have things and I missed him very much when I was working. He didn't believe me.

\section{Becky (9)}

Becky is the youngest of three children in a closely knit family. Even though her mother is currently attending a university, the two of them find time for relaxed conversation about all sorts of topics. Writes her mother:

Becky and I are watching The Muppet Anniversary Show. The date 1957 flashes underneath. At that Becky laughs and gets a gleeful look in her eye: "Mom, how long were you alive? I mean when were you born?" "1948." She starts laughing quite uncontrollably. "Wow, are you old. I'm young! I was born in 1979." "I know, I was there."

Unlike Ryan or Erik, Becky seems to be under relatively little surface stress at home or school. Yet she betrays a different kind of anxiety, concern over the longer-range issue of going to college. Recently, she has been hearing about her older brother's plan to attend college in the fall.

Becky, Sue (sister, age 13) and I are having dinner at Taco Bell. Over our Burrito Supremes Sue starts the conversation. "Would you and Dad be mad at me if I didn't go to college?" "No, Becky, we wouldn't be mad, but you'll have to make other plans." "How about a clerk at K-Mart?" Sue laughs and says, "Becky, you have to do more with your life than be a clerk at K-Mart." Becky has a good answer, "Yeah, well, when I get fired from there I'll get a different job." Now Sue is laughing harder. "Why would you want to get fired?" "Never mind. I really want to go to college anyway. I think I'll be a doctor. How long does a doctor go to college?" "Eight years." "I don't think I want to be 28 years old when I finish college. I'll be something else." 
With her older brother leading the way, Becky is testing the waters of her own long-term future, toying with options that receive playful derision from her sister and serious consideration from her mother.

Becky has a more active posture toward her future than either Ryan or Erik. We see her turning over in her mind the idea of going to college; yet we also see her teasing her mother about being old in comparison with her own tender age. One day a close friend of the family dies at the relatively young age of 61 , and Becky insists that she should be permitted to visit the funeral home to see her in the casket. In the conversation that follows, she raises the question of the puzzling connection between death and age:

"Mom, when I die will you be sad?" "I hope, Rebecca, that I will no longer be alive when you die." "You mean you'll be dead first?" "I am older than you, so I would expect to die first." "How old will I be when you die?" "Well, that depends on how old I am when I die." "How about if I'm 50 and you die?" "I was 30 when you were born, so I'd be 80 years old if you're $50 . "$ "Mom, that's old enough, isn't it?" "Old enough for what?" "To die." "Sure, Becky, 80 is plenty old enough." "But, some people live longer, right?" "Yes, your Great-Grandma is 91 now." "But some people die sooner, like Mrs. Skinner. I hope you don't die until I'm older."

This conversation begins with Becky's assumption that she'll die before her mother does. For a brief moment Becky glimpses her future death, but her mother quickly deflects the image, shifting attention to the greater likelihood of her own demise. Psychologically, it is not unlike a mother who sacrifices her life to shield and save the child.

A somewhat analogous exchange had occurred the previous summer, bringing out a similar protective response. Becky's mother and father had both decided to return to college in the fall.

The kids all thought it was pretty neat having their parents go back to school, or so we thought. One day after I'd been talking to a neighbor about going back to school Becky asked "Mom, when do you and Dad leave?" "Leave? Leave for where?" "Leave for college. When do you and Dad go?" Becky was concerned and suddenly I realized all this time her Dad and I had been bubbling about "going back to college" she was agonizing over our departure. I went to her and hugged her. "Becky, Dad and I aren't going away to college. We'll be staying right here at home and going to school. Like you do." I could almost see the weight drop from Becky's shoulders. "You are?" "Yes, did you really think we were both going away to college?" "Yes." "Becky, who did you think would take care of you while we were gone?" "John." (John is her 17 year-old brother-not a good parent substitute.) "Oh, honey, we wouldn't do that." And I hugged her real tight. I thought about how she must have been dying inside as we made plans to go back to college.

So Becky's uncertainty about her place in the life of the family receives gentle reassurance from her mother. But inwardly she faces the pos- 
sibility of abandonment. Probably more family support of this kind will be needed before she is able to look squarely at her future.

\section{Myra (9)}

Like Ryan and Erik, Myra lives with a divorced mother. But Myra's mom does not have to work, so she devotes full attention to obtaining a teaching certificate in history. She and her daughter are able to spend much time together, and each gains a deep sense of satisfaction from being with the other. Mother has a special love for history, which she eagerly shares with Myra. They often engage in animated conversations about the past, and talk playfully about what the future may bring. They seem to feel the world as a dynamic and changing environment that will gradually open them onto an exciting and enlarged stage. Mother says,

My sister and I were talking about Peter the Great and Myra cut into the conversation: "Is Cleopatra history?" "Yes." "Then I love history; if Cleopatra is history, I'm history! I love Cleopatra. I didn't know she was history." "Sure she is honey. Anything from the past is history. You were a part of history in the making when you watched the space shuttle explode. When you're in high school, you'll be hearing about it in your history class, but you'll know about it because you saw it!"

The two sisters then resume their own conversation, while Myra sits quietly nearby, weighing perhaps the meaning of her mother's thoughts about history in the making. Once more she breaks into the conversation;

"You know, Mom, when you're little like me, it's hard to think when you grow up and have kids how you can handle it. It's neat to think that you'll be able to help them with things-ya know, I mean like history, and bedtime stories. I'll be able to tell them because I saw it happen with my own eyes, and I'll be able to help them."

Myra's mother is intensely involved in her own child's education and vision of the world. It is a vision of almost limitless horizons, with the great panorama of the past laid out behind them and an expansive future ahead. One evening, for instance, they see a television commercial for an upcoming special called "America, You're Too Young to Die."

"Mom, why is America too young?" "Because it's only officially 210 years old!" "That's not young!" "It is when you consider how long people have been living on the European and Asian continents." "Well, isn't America as old as the rest of the world?" "It's as old as the rest of the earth, but what they mean is how long people have been living on certain parts of the earth. It took thousands of years before someone was courageous enough to keep sailing long enough to bump into America." "Oh. Why were people living in those other countries then?" "Because, when God first put people on the earth, he put them in Asia, and when they had kids and their kids had kids, there were more and more people coming into the world, and they spread out, until now there are people living all over the world." "Is Holland young too?" "No, all of the countries in Europe are thousands of years older than America." "If Holland is that old, I hope it doesn't die be- 
fore I can go there." (Myra has always had a special thing about Holland and Dutch shoes.) "Don't worry, I'm sure it will be here at least as long as the rest of the earth." "Good, 'cause I don't want anything to happen to it! How long will the earth be here?" "As long as God wants it to be." "That will probably be a long time, then."

Their singular life worlds seem somehow nested in the greater context of a world time that the mother so aptly describes. They both feel the wonder of being alive and fragile in such a powerful and dynamic climate of history.

For some time now Myra and her mother have been riding this crest of time toward a common future. But recently they have begun to glimpse a different future, a time when their worlds will begin to split off from each other. And that new future is accompanied by mixed feelings. For example, Myra has been taking ballet lessons over the past several years. And now she is striving to reach the critical threshold of going en pointe.

Myra and I are listening to some classical music, and she is dancing around like a little prima ballerina. She suddenly comes and jumps into my lap, and hugs me. "Oh Mommy, I just can't wait until I'm old enough to go en pointe. Do you know that it will be the most best day of my best, best life? How much longer do I have, Mama?" "Only about eight months now. But remember, that's only if Mrs. Simpson says that you're ready." "Oh, I'll be ready all right. I'm so lucky! Oh, I just can't wait! Oh, hurry up me, and grow, grow, grow. You'd think that since I'm so tall, I'd be older than I am. But I'm not. But I will be soon, won't I Mom?" "Too soon for me, I'm afraid!"

In a few years Myra will be a teenager, and mother and daughter are both acutely aware of the fact. So when a notice arrives from school that fourth-graders will be shown a sex education film if their parents sign a consent form, Myra's mother is quick to sign up, even though Myra herself is not so sure. But after seeing the film, she bubbles with excitement at the idea of becoming a young woman. But it is a qualified excitement. Myra asks:

"Does it hurt while your body is growing into a woman?" "No, honey, it doesn't hurt. It's just a kind of gradual process that happens, and your body changes over a period of time. It's not like you go to bed one night as a little girl, and wake up in the morning with a woman's body!" "Oh, I wondered about that! That would be funny, wouldn't it Mom? But if it did hurt, I wouldn't want to be a woman ever. Sometimes I don't want to be a woman anyway."

Tension is increasing daily around the anticipated changes in Myra's growing body. Mother and daughter are having a lively exchange about how to deal with boys, a few of whom have already asked Myra "to go with them." Mother says that when Myra reaches 16 she can go to parties and school dances, but only on the condition that she never gets into a car with someone who's been drinking or is high: 
"You just call me, and I don't care how late it is, or how far away, and I'll come and get you." "Oh, I promise Mom! I am never going with someone in their car like that. And if anyone tries to get me to take a drink like they did to Andy, I'll just tell them no, and I don't care what other kids would think or even if they call me names. Because I have goals, and I want to be a veterinarian, and a dancer, and I'll never let anyone take that away from me just because they want me to sneak a drink with them! Mommy, I just know I'm going to have such a great future like I have a great now. Would you still pick me up if I was in Japan or somewhere like that?"

Both mother and daughter are acutely aware of the insistent breeze that blows with ever increasing strength from Myra's future. Sometimes they try to pin down exactly how and where Myra is located in this emerging maelstrom of time. One day Myra announces,

"You know Mom, I was telling Grandma this morning that I look like halfteen and half-kid because my nails are all shiny, but I had on jeans, and a sweat shirt, and tennis shoes." "You were right, because you're pre-teen, and that's half-teen and half-kid!" "Pre-teen? I never heard of that. I just thought I would be a little kid, and then I would be a teenager. When is preteen?" "It's the time between being a child, and being a teenager. About ages ten to twelve, I suppose. It's a transition stage, where you sort of gradually grow out of being a child, into being a teen. You don't just wake up one morning and discover that you're a teen. It happens gradually." "Oh. That makes sense, Mom. I should have thought of that. But since I'm not ten yet, I'm not really a pre-teen. Will you tell me when I'm a pre-teen, Mom?" "I'd say you're one now, honey. Nine and a half is pretty close to ten, but really, it's more in the way you act, and your way of thinking, rather than reaching a certain age, that makes me think of you as a preteen." "Yeah, and I sure don't act like a baby anymore, do I Mom?"

So Myra and her mother live in a vivid and promising world, vulnerable, of course, to the vagaries of life's uncertainties, but strongly bolstered by their shared confidence in Myra's future. It is a future that beckons all the more brightly in light of a common past that they both remember and think about. In a burst of characteristic affection, Myra says:

"I hope you don't mind, Mom, if I keep being your little girl for a while longer, or for a long time longer." "I don't mind one bit, sweetheart! And besides, even when you grow up and have kids of your own, you'll still be my little girl. I'll always remember the very first moment I saw you, and all the special times we had when you were a little girl."

As Myra reflects on her good fortune to be preparing for a future that is underwritten by such strong love and support from her mom, she finds herself thinking about her family's deep past, somehow to explain it, to see it as part of a larger pattern of history.

"Really, I should say that Grandma is the best Mom, 'cause she had you. But then I could say her Mom who birthed her was the best Mom, and then her Mom, and her Mom, and all the way back to the first person in the 
world! We must have had a great family all the way back to the beginning, when there was the first family who lived."

Myra's vision of the deep past has a cosmic perfection about it. Curiously, it is a world undisturbed by any male presence or influence.

\section{A Brief Hermeneutic}

These portraits of mother and child suggest that children live toward at least five different futures. The first comes around again and again. It is perpetually within reach, but the socially imposed task for children is to bring it more routinely and more fully under their control and responsibility. For instance, a mother reports that her eight-year-old son has been unreliable about getting ready to leave the house promptly at 7:30 in the morning. So, she writes, "we're going to go back to a little chart, with pictures that say what we need to do at night and in the morning. It was very effective last year and gave the responsibility without my nagging."

This mother is working with her child to find an effective approach to their daily time management problems. Such problems involve a first and most immediate future, what might be called the routine future. It is this future that both Ryan and Erik struggle with under the diminished conditions of their divorced home lives.

The second future is more remote and remains tantalizingly beyond reach. It includes all sorts of anticipated new experiences such as Myra's going en pointe or Ryan's first deerhunt. The child can try to prepare mentally and physically for these novel experiences, but it is not possible to bring them under immediate, routine, or direct control. They are a part of what might be called the emergent future.

The third future is bound up with the anticipated transformation of the child's lived body into an altogether different way of being in the world. The awaited metamorphosis into puberty and adolescence is nearest on the horizon, but beyond this sexual transformation stands the farther, barely discernible, transition to adulthood; and farther still, the almost unimaginable transfiguration into old age. The child gauges these stages of growth and change by comparing his or her own condition to the physical and behavioral conditions of elderly, adult, and adolescent people. As with little Myra, the child can only dream what new experiences of the world will be wrought by these successive transformations of the lived body.

The fourth future arises initially from awareness of this transformed future, but it soon transcends that image to become an awareness of a different sort. The child begins to sense that the world itself has a history and is evolving, and sees that his or her allotted time in the world is finite. People are continually moving across the stage of life, with new individuals appearing at birth, and others disappearing at death, in a great 
cycle of exits and entrances. The child is on that stage, in that performance, and not, as formerly thought, sitting out in the audience where life continues when the show is over. The child is beginning to understand that while the performance itself may go on indefinitely, particular appearances on stage are temporary. Whether the child's role in society turns out to be a cameo or lead part, she or he now knows that eventual death and departure from that stage is inevitable and irreversible. It is this very inevitability that Becky saw for a brief moment before her mother so deftly shielded her. In the following passage from his journal, Ionesco (1968) remembers the discovery of his own finite future as it first appeared to him in childhood:

When I was eight or nine, when I lived at the Mill, everything was joy, everything was presentness. The seasons seemed to spread out in space. The world was a decorative background, with its colours, now dark and now bright, with its flowers and grass appearing, then disappearing, coming toward us, moving away from us, unfolding before our eyes while we ourselves stayed in the same place, watching time pass, ourselves being outside time. Because of that, no doubt, anyone's death seemed mysterious, illogical, terrible: an emptiness in the present. Then, all of a sudden, there came a kind of reversal; it was as though a centrifugal force had projected me out of my immutability into the midst of the things that go and come back and go away for good. Worse still, I suddenly had the feeling that things stood still, while I was moving away from them. At fifteen or sixteen it was all over, I was in time, in flight, in finiteness. The present had disappeared, there was nothing left for me but a past and a tomorrow, a tomorrow which I was already conscious of as past. (p. 11)

At the foundation of these four distinctly different ways of being toward the future (routine, emergent, transformed, finite) there seems to be yet a fifth future, a cosmic future. It lies on the other side of the child's whole life. It envelops the world, giving it an eternal cast. This future has a mythic quality to it, is drawn to science fiction, space stories, talk of God, and is almost indistinguishable from the deep past. It is a world with endless possibilities that are unfettered by earthly limitations. This cosmic future is perhaps hinted at in Erik's description of a timeless world. It is even more strongly suggested by Myra's feeling that her limitless future is somehow assured by the long march of human and prehuman history and evolution. In another mother's journal, eight-year-old Kevin says that the world, the planets, and outer space are all the future. Seven-year-old Mike equates the future with several things: with being in space, with the movie Return to $\mathrm{Oz}$, with monsters and scary creatures, and even with ancient cavemen and dinosaurs. And the youngest commentary on the cosmic future comes from four-year-old Cindy. Her chronicler writes, "Out of the clear blue Cindy said, 'If I get big I'm going up to God then. God's got swing sets. Before you go to God you have to be dug in the ground. I'm going to die. I'm getting bigger.'” 
Could it be that little Cindy's fantastical observation about herself, though based on the mysterious term God, is nonetheless a meaningful statement about her sense of a cosmic future? Is there not, even in this very young life world, an awareness of the future as essentially unbounded by death or other limitations? Cindy's apparent non sequitur, "I'm going to die, I'm getting bigger," is reminiscent of mature visions by great writers who have pointed to a future of cosmic proportions (Bachelard, 1969; Eliot, 1943; Needleman, 1964).

\section{References}

Bachelard, G. (1969). The poetics of reverie: Childhood, language, and the cosmos. Boston: Beacon Press.

Eliade, M. (1959). Cosmos and history: The myth of the eternal return. New York: Harper \& Row.

Eliot, T.S. (1943). Four quartets. New York: Harcourt, Brace and World.

Freud, S. (1960). A general introduction to psychoanalysis. New York: Washington Square Press.

Heidegger, M. (1962). Being and time. London: SCM Press.

Ionesco, E. (1968). Fragments of a journal. New York: Grove Press.

Merleau-Ponty, M. (1962). Phenomenology of perception. New York: Humanities Press.

Needleman, J. (1964). A sense of the cosmos. New York: Dutton.

Sartre, J.-P. (1966). Being and nothingness. New York: Washington Square Press. 